\title{
Rat endometrial Vdup1 expression: changes related to sensitization for the decidual cell reaction and hormonal control
}

\author{
David G Simmons and Thomas G Kennedy \\ Departments of Physiology and Pharmacology, and Obstetrics and Gynaecology, University of Western Ontario, \\ London, Ontario, Canada, N6A 5C1
}

Correspondence should be addressed to Thomas G Kennedy; Email: tom.kennedy@fmd.uwo.ca

D G Simmons is currently at Genes and Development Research Group, Department of Biochemistry and Molecular Biology, University of Calgary, Calgary, Alberta, Canada, T2N 4N1

\begin{abstract}
During implantation in rodents, attachment and invasion of embryonic trophoblast is accompanied by decidualization of the adjacent endometrial stroma. Decidualization can be initiated only when the endometrium is receptive, and this occurs for a short period in pregnancy. The molecular mechanisms underlying this phenomenon remain unclear. In the current study, using differential display and northern blot analysis, we found that steady-state levels of mRNA for vitamin $D_{3}$ upregulated protein 1 (Vdup1) were significantly higher in 'refractory' and 'delayed' endometrium compared with 'receptive' endometrium or endometrium undergoing artificially induced decidualization. Conversely, thioredoxin (Txn), a ubiquitously expressed cellular redox regulator known to promote growth and proliferation, was found to have elevated transcript levels within the decidualizing endometrium. VDUP1 has previously been shown to bind TXN and inhibit its action. In an inverse, but cooperative, relationship, these molecules have been implicated in regulating cell growth and proliferation in a number of tissues and during transformation to cancer. The Vdup1 mRNA is localized to the uterine stroma in the nonreceptive endometrium, the site of increased Txn mRNA levels during decidualization. In addition, Vdup1 mRNA levels are inversely regulated by progesterone and estrogen; prolonged progesterone exposure stimulates an increase in Vdup1 mRNA levels whereas estrogen decreases Vdup1 transcript levels. Together, these results suggest a novel mechanism by which suppression of the decidual response in the nonreceptive endometrium may occur.
\end{abstract}

Reproduction (2004) 127 475-482

\section{Introduction}

Successful implantation depends upon the synchronized maturation of the embryo and the endometrium; the development of the embryo to the expanded blastocyst stage must coincide with hormone-dependent changes within the endometrium that render it receptive to implantation (Psychoyos 1973). Asynchrony between these events can delay or prevent implantation, as the uterus is receptive for only a short period in pregnancy or pseudopregnancy or when the uterus has been prepared with a specific regimen of hormones (Psychoyos 1973, Kennedy \& Ross 1997). Interestingly, the nonreceptive uterus is one of the few tissues into which the embryo will not normally implant (Fawcett 1950, Kirby 1963, 1965). While the hormonal requirements for the onset of uterine receptivity in the rodent, as well as those underlying the phenomenon of delayed implantation, have been known in detail for over 30 years (Yochim \& De Feo 1963, Psychoyos 1973), a complete picture of the molecular mechanisms orchestrating the transition from a nonreceptive to a receptive endometrium, and vice versa, remains elusive.

Through the use of mRNA differential display (ddRTPCR), we exploited both the tight hormonal control for the onset of uterine receptivity and an established model for the induction of a sensitized endometrium in ovariectomized, hormone-treated rats (De Feo 1963, Psychoyos 1973, Kennedy \& Ross 1997), and identified vitamin $\mathrm{D}_{3}$ upregulated protein 1 (Vdup1) as a gene upregulated in the nonsensitized rat endometrium. This was the case for both the refractory endometrium (the endometrial state immediately following receptivity) and during a model of delayed implantation, the prereceptive state that supports the survival of an embryo in diapause until sensitization is achieved. VDUP1 has been shown to interact with thioredoxin (TXN) by binding to its active site and inhibiting its biologic action 
(Nishiyama et al. 1999, Junn et al. 2000, Yamanaka et al. 2000). TXN has been implicated in numerous cellular processes, including the promotion of cell proliferation, the inhibition of apoptosis and the regulation of transcription factor binding and antioxidant activity (reviewed in Nishiyama et al. 2001). In addition, TXN is highly expressed in the uterus of mice (Osborne et al. 2001), rats (Sahlin et al. 1997) and humans (Perkins et al. 1995), as well as in the highly invasive cytotrophoblast cells of the human placenta (Perkins et al. 1995). We show that Txn mRNA levels increase within the decidualizing endometrium, in contrast to Vdup1. The spatial and temporal expression for Vdup1 and Txn mRNA presented in the current study, and the opposing actions of these molecules reported in the literature, suggest that these molecules may interact within the endometrial stroma to modulate the potential for the decidual response in the rat.

\section{Materials and Methods}

\section{Animals and tissue preparation}

Female Sprague-Dawley rats (200-225 g body mass: HarIan Sprague-Dawley, Indianapolis, IN, USA) were housed in temperature- and light-controlled conditions (14 h light, $10 \mathrm{~h}$ dark with lights on from $0500 \mathrm{~h}$ to $1900 \mathrm{~h}$ ) with free access to food and water. Animals were ovariectomized under ether anesthesia (BDH, Toronto, ON, Canada). To obtain rats with uteri differentially sensitized for the decidual cell reaction, estradiol $\left(E_{2}\right)$ and progesterone $\left(P_{4}\right)$ (Sigma) were administered subcutaneously (s.c.) in sesame oil as previously described (Kennedy \& Ross 1997). Some rats received a bilateral injection of $100 \mu$ l sesame oil into the uterine lumen on the equivalent of day 5 of pseudopregnancy to induce decidualization (Finn \& Keen 1963). Rats receiving intraluminal injections of sesame oil on day 5 and their controls continued to receive daily s.c. injections of $E_{2}$ and $P_{4}$ in sesame oil until they were killed (Kennedy \& Ross 1997). Uteri were collected on the morning of each day of the equivalent of days 4-10 of pseudopregnancy, and, unless stated otherwise, endometrium was separated from myometrium as described by Martel and Psychoyos (1978). All procedures involving animals were performed in accordance with the guidelines of the Canadian Council on Animal Care and the University Council on Animal Care at the University of Western Ontario.

\section{Identification of Vdup1 by differential display}

Changes in endometrial gene expression in endometrium differentially sensitized for decidualization were analyzed by the method of ddRT-PCR as described by Liang and Pardee (1992) and modified by Simmons and Kennedy (2000). In summary, following separation of endometrium from myometrium, it was immediately homogenized in guanidinium isothiocyanate buffer, and total RNA was extracted (Chomczynski \& Sacchi 1987). After DNAse I (Gibco-BRL, Burlington, ON, Canada) treatment, total RNA was reversed transcribed using the degenerate $3^{\prime}$ primer $T_{11} M C$, where ' $M$ ' is either $C, G$, T or $A$. PCR reactions were then performed using the same $3^{\prime}$ primer and the $5^{\prime}$ primer GATCTGACAC in the presence of $\left[\alpha-{ }^{35}\right.$ S]dATP (Bauer et al. 1993). The PCR products were run on standard $6 \%(\mathrm{w} / \mathrm{v})$ polyacrylamide-urea sequencing gels, transferred to filter paper, dried and exposed to radiograph film. After development of the film, the apparently differentially expressed cDNA band was cut out of the dried gel, rehydrated, precipitated and then reamplified using the same $\mathrm{PCR}$ conditions as for differential display, except that dNTP concentrations were 10-fold higher and $\left[\alpha-{ }^{35}\right.$ S $]$ dATP was not present. Half of the reamplification products were run in a $1.5 \%(\mathrm{w} / \mathrm{v})$ agarose gel and stained with ethidium bromide for visualization; the remainder was kept for cloning into the pGEM T-easy vector (Promega). Sequencing was performed using an automated fluorescent DNA sequencer (John P. Robarts Research Institute DNA Sequencing Facility, London, ON, Canada).

\section{northern blot analysis}

An amount of $10 \mu \mathrm{g}$ of total RNA was denatured and subjected to electrophoresis in a denaturing gel as previously described (Sambrook et al. 1989). RNA was then transferred to Hybond-N membrane (Amersham) by capillary transfer and cross-linked by exposure to $1.2 \times 10^{5} \mu \mathrm{J} / \mathrm{cm}^{2}$ of UV energy (Hoefer Pharmacia Biotech, San Francisco, CA, USA). northern blot analysis was performed as described by Church and Gilbert (1984), with some modifications. Briefly, membranes were prehybridized in Church buffer $(7 \%$ (w/v) SDS, $0.25 \mathrm{~mol} \mathrm{Na} \mathrm{HPO}_{4} / \mathrm{l}(\mathrm{pH} 7.2), 1 \mathrm{mmol} \mathrm{EDTA} / \mathrm{l}$ and $1 \%$ $(\mathrm{w} / \mathrm{v}) \mathrm{BSA})$ at $65^{\circ} \mathrm{C}$ for at least $30 \mathrm{~min}$. The cDNA amplicon isolated from the ddRT-PCR gel was used as a template to synthesize ${ }^{32} \mathrm{P}$-labeled DNA probes for northern blot hybridization. An amount of $25 \mathrm{ng}$ of cDNA was labeled by the random-priming technique in the presence of $\left[\alpha-{ }^{32} \mathrm{P}\right] \mathrm{dCTP}$ (Amersham) with an oligo-labeling kit (Random Primers Labeling System; Gibco-BRL). Hybridizations were carried out at $60^{\circ} \mathrm{C}$ for $20 \mathrm{~h}$. The membranes were subsequently washed three times (15 min each) at $65^{\circ} \mathrm{C}$ in $20 \mathrm{mmol} \mathrm{Na}{ }_{2} \mathrm{HPO}_{4} / \mathrm{l}(\mathrm{pH} 7.2)$, with $4 \%(\mathrm{w} / \mathrm{v})$ SDS and subjected to autoradiography at $-70^{\circ} \mathrm{C}$ with a Biomax MS TranScreen-HE intensifying screen (Eastman Kodak) for the appropriate exposure time. Blots were then stripped in $1 \mathrm{mmol}$ Tris/l, $1 \mathrm{mmol}$ EDTA/l and $0.1 \times$ Denhardt's reagent $(1 \times$ Denhardt's: $2 \%$ $(\mathrm{w} / \mathrm{v})$ BSA, 2\% (w/v) Ficoll and 2\% (w/v) polyvinylpyrrolidone, $\mathrm{pH}$ 8.0) for $2 \mathrm{~h}$ at $75^{\circ} \mathrm{C}$, and sequentially reprobed with radiolabeled cDNAs for Txn, thioredoxin reductase 1 (Txnrd1) and 18S rRNA. The autoradiographs 
were digitized using a Hewlett Packard Scanjet 4c/T scanner, and the densitometric intensity of each signal was quantified with Pharmacia ImageMaster VDS Video Documentation System Software, Version 2.0. The $18 \mathrm{~S}$ rRNA signal was used to determine the relative amounts of RNA loaded into each well and transferred to the membrane and to normalize Vdup1, Txn and Txnrd1 signals (Smith \& Hammond 1991).

\section{In situ hybridization}

At the time total RNA was isolated for the ddRT-PCR and northern blot analyses, some uterine horns were fixed by immersion in $4 \%(\mathrm{w} / \mathrm{v})$ paraformaldehyde for $24 \mathrm{~h}$. The horns were then rinsed in two changes of PBS and stored in $70 \%(\mathrm{v} / \mathrm{v})$ ethanol until embedded in paraffin and sectioned at $6 \mu \mathrm{m}$.

The vector, containing an amplicon cloned from the differential display experiments, was linearized and cRNA sense and antisense probes were synthesized in the presence of digoxigenin (DIG)-labeled rUTP (Roche Molecular Biochemicals, Laval, QC, Canada) according to the manufacturer's instructions. The in situ hybridization technique used has been described in detail previously (Harvey et al. 1995). Briefly, uterine cross-sections were dewaxed in xylene, rehydrated through an alcohol series to $2 \times \mathrm{SSC}$, digested in proteinase $\mathrm{K}$ at $37^{\circ} \mathrm{C}$ for $5-$ $7.5 \mathrm{~min}$, and acetylated by incubation with freshly prepared $0.1 \mathrm{~mol}$ triethanolamine $/ \mathrm{l}$ and $0.56 \%(\mathrm{v} / \mathrm{v})$ acetic anhydride at room temperature. After prehybridization at $50{ }^{\circ} \mathrm{C}$ for $4 \mathrm{~h}$ in a $50 \%(\mathrm{v} / \mathrm{v})$ formamide, $5 \times \mathrm{SSPE}, 1 \times$ Denhardt's solution, the sections were hybridized with $100 \mathrm{ng}$ of cRNA probe and $400 \mathrm{ng}$ of tRNA (in prehybridization solution) under a cover slip for $20 \mathrm{~h}$ at $50^{\circ} \mathrm{C}$ in a sealed humidified chamber. The sections were then washed extensively, treated with RNase and processed for immunologic detection of the DIG-labeled cRNA probe using anti-DIG antibodies at a dilution of 1:500 (Roche Molecular Biochemicals). Color development was allowed to continue until a signal (blue-purple precipitate) was detected. The color reaction for the sense cRNA-treated slides was terminated at the same time as for the antisense slides. Sections were then mounted using GVA-mount (Zymed Laboratories, San Francisco, CA, USA).

\section{Statistical analysis}

Experiments quantifying changes in mRNA levels by northern blot analysis were performed three times on separate groups of ovariectomized, hormone-treated rats (except when stated otherwise). The data were analyzed by within-blocks ANOVA, with experiments being considered blocks. Duncan's multiple range test was performed to determine differences between groups. $P<0.05$ was considered significant.

\section{Results}

\section{Identification of Vdup1 as a gene differentially expressed during the peri-implantation period}

Vdup1 was isolated from a differential display screen aimed at identifying changes in gene expression associated with the onset and subsequent disappearance of uterine sensitization for the decidual cell reaction. Specifically, total RNA (pooled from groups of 7 animals) at the equivalent of days 4, 5 and 6 of pseudopregnancy, as well as RNA from two groups of day 5 animals receiving inappropriate doses of $E_{2}$ on the evening of day 4 (day 5 'high $\mathrm{E}_{2}^{\prime}$ and day 5 'low $\mathrm{E}_{2}^{\prime}$ ), were compared. Vdup1 was identified as a gene upregulated within the day 6, 'refractory' endometrium (Fig. 1). northern blot analysis confirmed the expression pattern seen by ddRT-PCR, as Vdup1 mRNA levels were significantly higher within the 'refractory' day 6 endometrium than within the 'sensitized' day 5 and 'neutral' day 4 endometrium (Fig. 2, $P<0.05$ ). Significantly higher levels of Vdup1 mRNA were also observed in the endometrium of animals in the day 5, low $E_{2}$ group (low $\mathrm{E}_{2}$ group, Fig. 2, $P<0.05$ ). However, rats temporally correct for sensitization (equivalent of day 5 of pseudopregnancy) but with nonsensitized endometrium, as a consequence of a high dose of $E_{2}$ on the evening of day 4, had no significant increase in Vdup1 mRNA levels (high $\mathrm{E}_{2}$ group, Fig. 2).

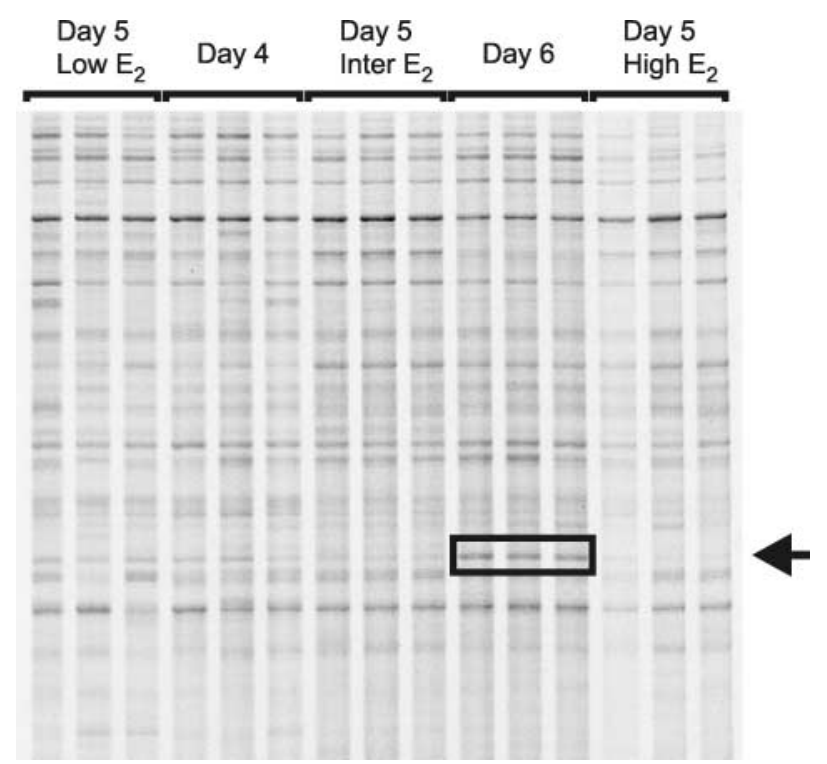

Figure $1 \mathrm{mRNA}$ differential display gel showing the cDNA profile for endometrial RNA for the primer combination T11MC (degenerate $3^{\prime}$ primer) and GATCTGACAC ( $5^{\prime}$ primer). The total RNA being compared (pooled from the uteri of seven animals for each group) includes endometrial RNA from the equivalent of days 4, 5 or 6 of pseudopregnancy and two endometrial RNA samples from day 5 rats that received inappropriate doses of $E_{2}$ on the evening of day 4 (low and high $E_{2}$ ). PCR reactions were run in triplicate, and the black arrow indicates the band representing Vdup1. 
A

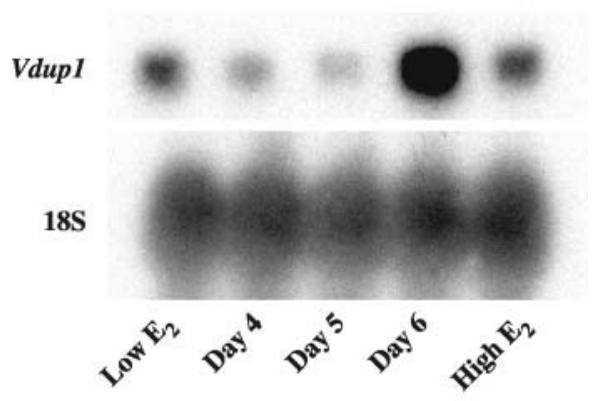

B

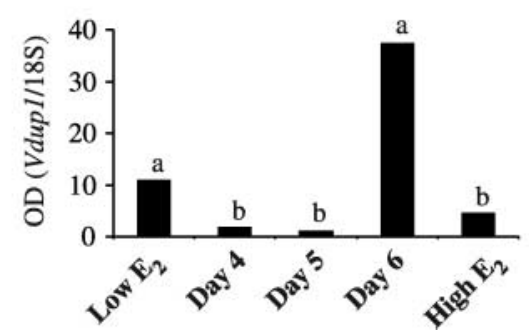

Figure 2 Profile of Vdup1 mRNA levels within differentially sensitized rat uteri by northern blot analysis. (A) Endometrium was isolated from the uteri of pseudopregnant animals on the equivalent of day 4 , day 5 (maximally sensitized -intermediate $\mathrm{E}_{2}$ ) and day 6 , and from two groups of animals with temporally correct day 5 uteri that were hormonally nonsensitized (day 5 high $\mathrm{E}_{2}$ and day 5 low $\mathrm{E}_{2}$ ). Total RNA $(10 \mu \mathrm{g})$, pooled from seven animals per group, was loaded into each lane, and ${ }^{32} \mathrm{P}$-labeled probes for Vdup1 and $18 \mathrm{~S}$ rRNA were hybridized to the membranes. The experiment was performed three times with independent RNA samples with similar results. (B) Intensities of the signals for Vdup1 were normalized with 18S rRNA signals, and the average of the three replicates is depicted in the bar graph. Signal intensities from the day 5 , intermediate $\mathrm{E}_{2}$ groups were arbitrarily set at one. Bars with the same superscript are not statistically different from one another.

\section{Northern blot analysis of Vdup1 and Txn mRNA expression during pseudopregnancy and oil-induced decidualization}

Further characterization of Vdup1 mRNA expression from days $6-10$ of pseudopregnancy, in the presence (' $S$ ') or absence (' $\mathrm{N}$ ') of artificially induced decidualization, indicated a sustained increase in Vdup1 transcript levels within the refractory, nondecidualizing endometrium, whereas transcript levels remained low within the decidualizing endometrium (Fig. 3, $P<0.05$ ). In contrast, mRNA levels for $T x n$ increased during decidualization but remained low within the refractory endometrium (Fig. 3, $P<0.05)$.

\section{Localization of Vdup1 and Txn mRNA expression within the refractory and decidualizing uterus by in situ hybridization}

In order to elucidate a possible site of action for Vdup1, we localized the spatial expression pattern of Vdup1 mRNA within the day 7 pseudopregnant, 'nonstimulated'
$\mathbf{A}$

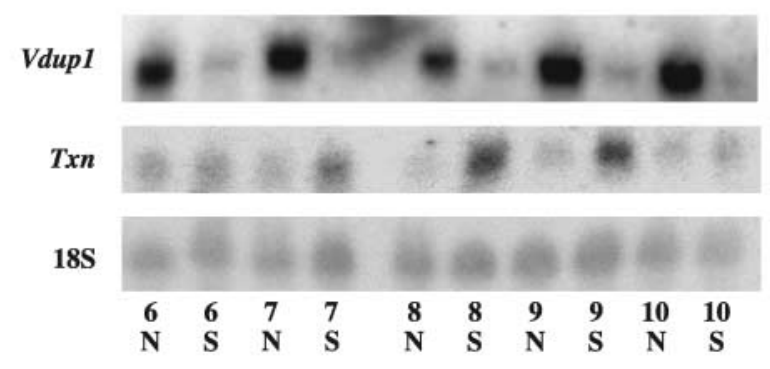

B

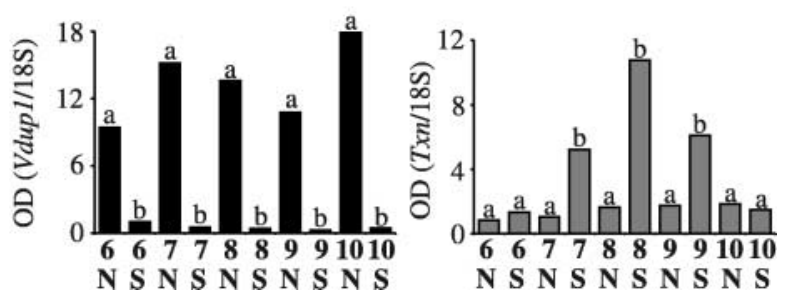

Figure 3 Expression of Vdup1 mRNA within the rat endometrium during pseudopregnancy as determined by northern blot analysis. (A) Endometrium was isolated from pseudopregnant uteri as described previously. Total RNA was isolated from the endometrium of uteri at the equivalent of days $6-10$ of pseudopregnancy. Some animals received an intraluminal injection of $100 \mu \mathrm{l}$ of sesame oil into the lumen of the uterus (' $\mathrm{S}$ ' - stimulated) at around noon on the equivalent of day 5 and were killed $1-5$ days later. These animals were undergoing artificially induced decidualization at the time of sampling. Those animals that did not receive the intraluminal injection of sesame oil ( $\mathrm{N}$ ' - nonstimulated) were not undergoing artificially induced decidualization at the time of sampling. Numbers 6-10 refer to the equivalent day of pseudopregnancy. ${ }^{32} \mathrm{P}$-labeled probes for Vdup1, Txn and 18S rRNA were used sequentially in the hybridization. Each lane contained $10 \mu \mathrm{g}$ of total RNA pooled from seven animals. The experiment was performed three times with independent RNA samples with similar results. (B) Intensities of the signals for Vdup1 or Txn were normalized with 18S rRNA signals, and the averages of the three replicates are depicted in the bar graph. Signal intensities from the day 6 , 'stimulated' groups were arbitrarily set at one. Bars with the same superscripts are not statistically different from each other.

and 'stimulated' (decidualizing) endometrium by in situ hybridization. Vdup1 mRNA was highly expressed within the stromal compartment of nondecidualizing endometrium (Fig. 4A). However, by the equivalent of day 7 of pseudopregnancy, $48 \mathrm{~h}$ following the application of a deciduogenic stimulus, Vdup1 mRNA expression was detected in the stomal cells only on the periphery of the endometrium, while expression was absent within the decidualizing stroma immediately surrounding the uterine lumen (Fig. 4E). In contrast, Txn mRNA was expressed at low levels within the stroma and luminal epithelium of 'refractory' day 8 pseudopregnant endometrium (with slightly higher levels within the glandular epithelium Fig. 4C) but was highly elevated within the decidualizing stroma on day 8 of pseudopregnancy (Fig. 4F). No signals were obtained with the sense probes (Fig. 4B and D). 


\section{Hormonal control of Vdup1 and Txn mRNA expression in the pseudopregnant uterus}

A model of delayed implantation was used to explore further the regulation of Vdup1 mRNA expression by the ovarian steroids. Ovariectomized rats were given $96 \mathrm{~h}$ of
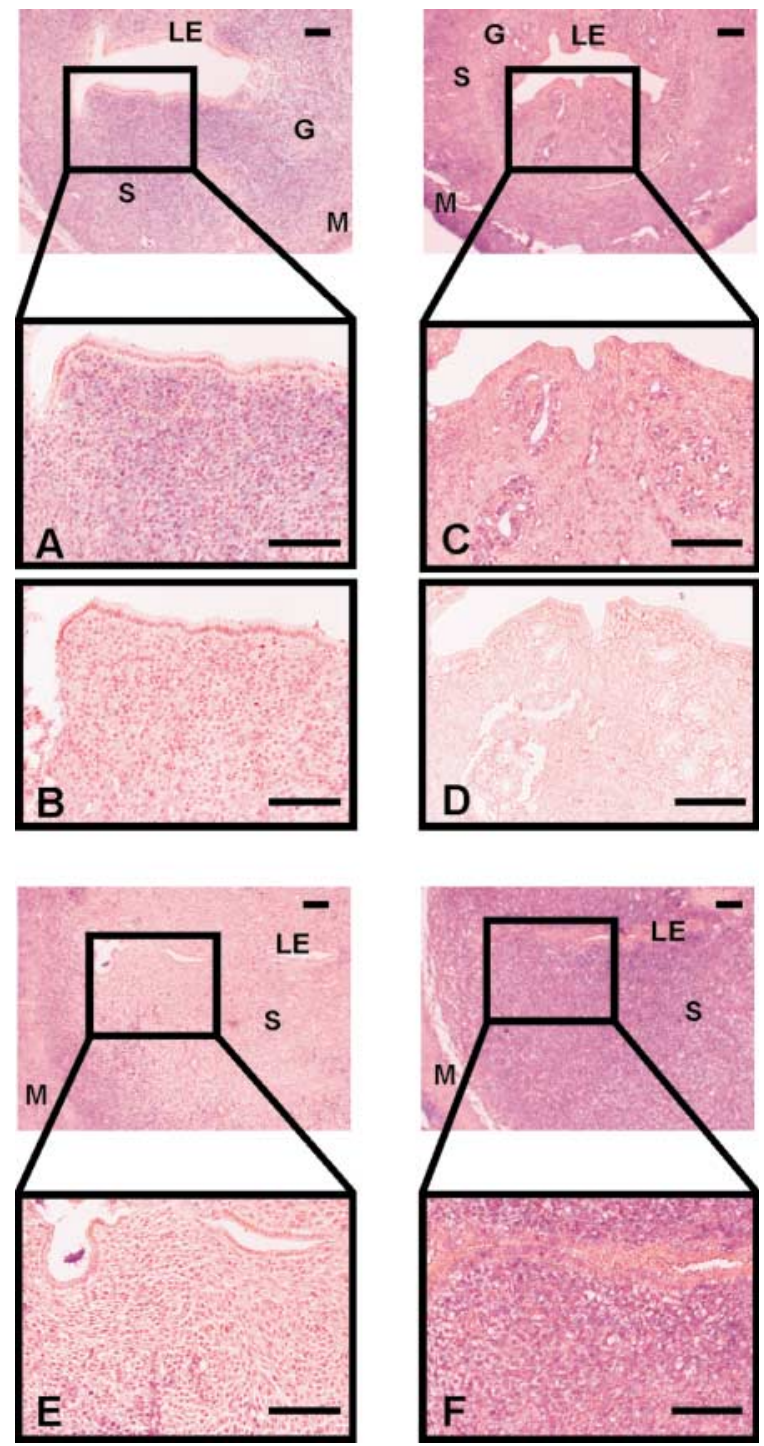

Figure 4 In situ localization of Vdup1 and Txn mRNA within the pseudopregnant rat uterus. Paraffin-embedded uteri were cross-sectioned and analyzed by DIG in situ hybridization for Vdup1 and Txn mRNA signals. $(A) \times 10$ magnification, antisense $V d u p 1$ probe hybridized to 'nonstimulated' day 7 pseudopregnant uteri. (B) $\times 10$ magnification, sense Vdup1 probe hybridized to 'nonstimulated' day 7 pseudopregnant uteri. $(C) \times 10$ magnification, antisense $T x n$ probe hybridized to 'nonstimulated' day 8 pseudopregnant uteri. (D) $\times 10$ magnification, sense $T x n$ probe hybridized to 'nonstimulated' day 8 pseudopregnant uteri. (E) $\times 10$ magnification, antisense Vdup1 probe hybridized to 'stimulated' day 7 pseudopregnant uteri. $(\mathrm{F}) \times 10$ magnification, antisense $T x n$ probe hybridized to 'stimulated' day 8 pseudopregnant uteri. $\mathrm{LE}=$ luminal epithelium, $\mathrm{G}=$ glandular epithelium, $\mathrm{S}=$ stroma and $\mathrm{M}=$ myometrium. Lower magnification panels are taken at $\times 4$ magnification and black bar $=100 \mu \mathrm{m}$ for all panels.
$\mathrm{P}_{4}$ treatment (after $48 \mathrm{~h}$ of $\mathrm{P}_{4}$ priming, further $\mathrm{P}_{4}$ treatment in the absence of $E_{2}$ results in a 'delayed' endometrium that will become sensitized only after $E_{2}$ exposure) followed by either more $\mathrm{P}_{4}$ ('delayed') or $\mathrm{P}_{4}$ plus $\mathrm{E}_{2}$ ('sensitized'). High levels of $V d u p 1$ mRNA were evident within the uteri of delayed animals, whereas much lower levels of Vdup1 mRNA were seen in the 'sensitized' animals following the termination of delay (Fig. 5A and B).

The effects of the ovarian steroid hormones $E_{2}$ and $P_{4}$ on endometrial Vdup1, Txn and Txnrd1 mRNA levels were investigated in ovariectomized rats. Animals injected
$\mathbf{A}$

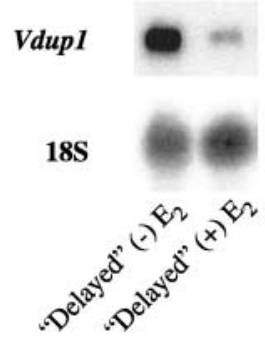

B

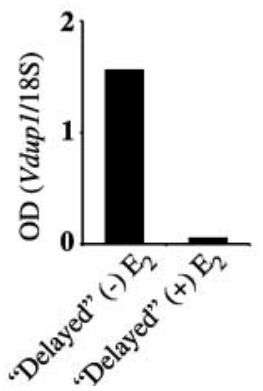

C

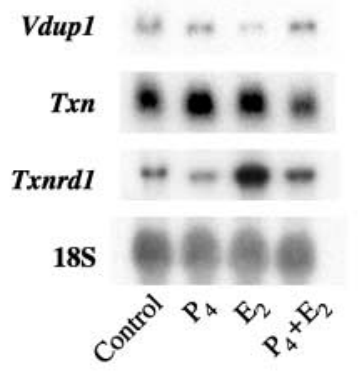

D

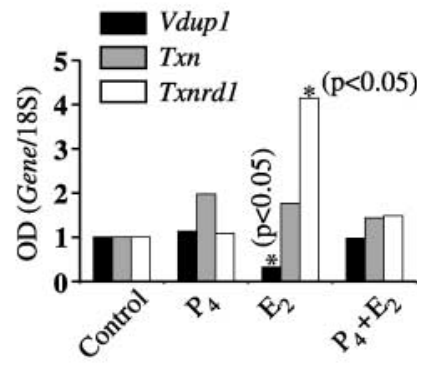

Figure 5 Hormonal control of Vdup1 and Txn mRNA levels within the rat uterus in vivo as determined by northern blot analysis. (A) Animals were ovariectomized and given $4 \mathrm{mg} \mathrm{P}_{4}$ daily for 4 days to induce a state of 'delayed implantation', and they then received $4 \mathrm{mg}$ $\mathrm{P}_{4}$ plus $0.3 \mu \mathrm{g} \mathrm{E}_{2}$ to induce sensitization, or $4 \mathrm{mg} \mathrm{P}_{4}$ alone to maintain the 'delay'. Animals were killed $18 \mathrm{~h}$ later, and total RNA from whole uteri was isolated. There were three animals in each group. In the northern blot analysis, $10 \mu \mathrm{g}$ of RNA was used. ${ }^{32}$ P-labeled cDNA probes for Vdup1 and $18 \mathrm{~S}$ rRNA were used as previously described. (B) Intensity of the signals was normalized with the signals for $18 \mathrm{~S}$ rRNA (Vdup1/18S rRNA), and the averages of the two replicates are depicted in the bar graph. The values for the control groups were arbitrarily set at 1. (C) Animals were ovariectomized and given a single dose of either $1 \mu g \mathrm{E}_{2}, 4 \mathrm{mg} \mathrm{P}_{4}, 1 \mu \mathrm{g} \mathrm{E}_{2}$ plus $4 \mathrm{mg} \mathrm{P}_{4}$, or vehicle (sesame oil). Uteri were collected $18 \mathrm{~h}$ later, and total RNA from whole uterus was isolated. There were three animals in each group. In the northern blot analysis, $10 \mu \mathrm{g}$ of RNA was used.

${ }^{32}$ P-labeled cDNA probes for Vdup1, Txn and 18S rRNA were used for hybridization. (D) Intensity of the signals was normalized with the signals for $18 \mathrm{~S}$ rRNA (Vdup1/18S rRNA), and the averages of the two replicates are depicted in the bar graph. The values for the control groups were arbitrarily set at 1 . 
with a single dose of $E_{2}$ showed a significant decrease in Vdup1 mRNA levels while Txn mRNA levels were not significantly altered (Fig. 5C and D). $\mathrm{P}_{4}$ alone or $\mathrm{P}_{4}$ plus $\mathrm{E}_{2}$ in combination did not significantly alter expression of either Vdup1 or Txn mRNA levels over that of control, although it eliminated the $\mathrm{E}_{2}$-induced decrease in Vdup1 mRNA levels (Fig. 5C and D). Txnrd1 mRNA levels were significantly increased by treatment with $\mathrm{E}_{2}$ alone.

\section{Discussion}

Using differential display to uncover changes in gene expression associated with the onset and subsequent disappearance of uterine sensitization for the decidual cell reaction, the current study has identified Vdup1 as a gene upregulated within the 'refractory' endometrium (Fig. 1). Subsequent northern blot analysis confirmed the increase in endometrial Vdup1 mRNA levels following uterine sensitization (Fig. 2) and also indicated that this increase is sustained as long as the endometrium remains in a 'refractory' state (Fig. 3). In contrast, endometrial Vdup1 mRNA levels are not elevated following sensitization if decidualization has been initiated (Fig. 3). In situ hybridization experiments localized the site of Vdup1 mRNA expression to the stromal cells of the endometrium (Fig. 4). Together, these data suggest a possible role for VDUP1 in maintaining stromal cells of the endometrium in a refractory state.

Vdup1 was originally discovered as a gene upregulated during 1,25-dihydroxyvitamin $\mathrm{D}_{3}$-induced differentiation of HL-60 cells (Chen \& DeLuca 1994) and downregulated in $\mathrm{N}$-methyl- $\mathrm{N}$-nitrosourea-induced mammary tumors (Young et al. 1996), suggesting that VDUP1 may be involved in the regulation of cell growth and tumor suppression. The inference that VDUP1 functions as a negative regulator of cell growth and in tumor suppression has gained support recently, as a number of studies have shown a decrease in Vdup1 gene expression associated with the onset of various cancers, including breast (Butler et al. 2002), colon (Butler et al. 2002, Ikarashi et al. 2002) and B-cell lymphoma (de Vos et al. 2003). In addition, some studies have shown that an increase in VDUP1 protects against cancer and inhibits tumor cell growth (Butler et al. 2002, Goldberg et al. 2003, Han et al. 2003).

VDUP1 has also been implicated as a binding protein for the redox regulator TXN, binding to its active site and inhibiting its biologic activity (Nishiyama et al. 1999, Junn et al. 2000, Yamanaka et al. 2000). TXN has been shown to have a wide range of biologic activities, including growth promotion and proliferation, antioxidant activity, regulation of transcription factor binding and inhibition of apoptosis (reviewed in Nishiyama et al. 2001). It is possible that the growth inhibition effects of VDUP1 are mediated through TXN inhibition. In fact, Schulze et al. (2002) recently described a system in which VDUP1 and TXN have opposing effects on human aortic smooth muscle cell proliferation. Specifically, overexpression of
VDUP1 inhibited cell proliferation, in contrast to TXNstimulated cell proliferation, as well as prevented nuclear translocation of TXN in response to platelet-derived growth factor, a potent stimulator of aortic smooth muscle cell proliferation and TXN activity (Schulze et al. 2002).

Because VDUP1 has been shown to regulate cell proliferation and growth negatively through inhibition of TXN activity, and because TXN has been shown to be highly expressed in the uterus of mice (Osborne et al. 2001) and humans (Perkins et al. 1995), as well as in the highly invasive cytotrophoblast cells of the human placenta (Perkins et al. 1995), we investigated whether Txn mRNA levels would have an opposite expression pattern to that of Vdup1 in the rat endometrium. Indeed, Txn mRNA levels increased within the decidualizing endometrium but remained low within the nondecidualizing, refractory endometrium (Fig. 3). While Vdup1 and Txn mRNA levels within the endometrium appear to have opposing expression patterns, they are both induced in the endometrial stroma (Fig. 4). This converse temporal expression but shared spatial expression suggests that they may have linked, but opposing roles in stromal cell proliferation within the uterus, with TXN stimulating the proliferation of decidual cells and VDUP1 inhibiting cell proliferation in the refractory or nonsensitized endometrial stromal compartment.

In addition to verifying the results obtained by ddRTPCR, northern blot analysis also revealed a statistically significant increase in Vdup1 mRNA levels within the endometrium of animals in the day 5, low $\mathrm{E}_{2}$ group (low E2 group, Fig. 2). These animals, although temporally correct for sensitization (equivalent of day 5 of pseudopregnancy), were hormonally nonsensitized, as they did not receive $E_{2}$ on the evening of day 4 but only an injection of $\mathrm{P}_{4}$. By contrast, rats with nonsensitized endometrium on day 5 , as a consequence of a high dose of $E_{2}$ on the evening of day 4, had low levels of Vdup1 mRNA (high $\mathrm{E}_{2}$ group, Fig. 2). These data would indicate that prolonged $\mathrm{P}_{4}$ exposure in the absence of $\mathrm{E}_{2}$, a situation that simulates lactational delay of sensitization/receptivity, results in an increase in Vdup1 mRNA levels. To investigate this observation further, we used a model of delayed implantation. Ovariectomized rats were given $96 \mathrm{~h}$ of $\mathrm{P}_{4}$ treatment (after $48 \mathrm{~h}$ of $\mathrm{P}_{4}$ priming, further $\mathrm{P}_{4}$ treatment in the absence of $\mathrm{E}_{2}$ results in a 'delayed' endometrium that will become sensitized only after $E_{2}$ exposure) followed by either more $\mathrm{P}_{4}$ ('delayed') or $\mathrm{P}_{4}$ plus $\mathrm{E}_{2}$ ('sensitized'). High levels of Vdup1 mRNA were evident within the uteri of delayed animals, whereas low levels of Vdup1 mRNA were seen in the 'sensitized' animals following the termination of delay (Fig. 5A and B). The fact that Vdup1 mRNA is upregu lated within the endometrium during 'delayed implantation' further supports the hypothesis that VDUP1 may help to maintain a quiescent, nondecidualizing stromal cell population. In addition, $E_{2}$ administration, which is itself a known promoter of cell growth, is sufficient significantly to downregulate Vdup1 mRNA levels within the 
uteri of ovariectomized animals (Fig. 5C and D). The absence of an $\mathrm{E}_{2}$-induced increase in Txn mRNA (Fig. 5C and D) was unexpected, as Sahlin et al. (1997) showed an increase in Txn mRNA within the rat uterus in response to $E_{2}$, although this could be due to the fact that in their study $2.5 \mu \mathrm{g}$ of $E_{2}$ was injected, whereas we used only $1.0 \mu \mathrm{g}$. We did see, however, a significant increase in Txnrd1 mRNA levels in response to $1.0 \mu \mathrm{g}$ of $\mathrm{E}_{2}$ (Fig. 5C and D). TXNRD1 is a protein that reduces the oxidized, inactive form of TXN back to its active state (Holmgren \& Bjornstedt 1995). Presumably, an increase in Txnrd1 expression would translate into an increase in Txn activity within the cell. Together these data indicate that $E_{2}$ decreases Vdup1 mRNA levels and possibly increases TXN activity through decreased TXN inhibition and increased TXN recycling, while $P_{4}$ prevents the $E_{2}$ induced changes in gene expression. $\mathrm{P}_{4}$ alone does not induce an increase in Vdup1 mRNA levels, but, rather, a prolonged exposure to $\mathrm{P}_{4}$, as in the case of 'delayed implantation', is required (Fig. 5A and B).

The expression patterns of Vdup1 and Txn mRNA within the rat uterus presented in the current study, along with the established interaction of these proteins to regulate cell proliferation in other systems, positions these molecules as potential regulators of cell proliferation in the rat uterus around the time of embryo implantation. While the function of VDUP1 in the nonsensitized endometrium is probably the inhibition of TXN, this has yet to be established experimentally. Other TXN-independent functions may exist for VDUP1. In fact, a recent study by Han et al. (2003) showed that VDUP1 induced cell-cycle arrest and physically interacted with transcriptional corepressors, presumably inhibiting cell growth in a TXN-independent fashion. Clearly, more work is needed to clarify the function of VDUP1 within the endometrium during the peri-implantation period.

\section{Acknowledgement}

This work was supported by the Canadian Institutes of Health Research Grant MT-10414.

\section{References}

Bauer D, Muller H, Reich J, Riedel H, Ahrenkiel V, Warthoe P \& Strauss M 1993 Identification of differentially expressed mRNA species by an improved display technique (DDRT-PCR). Nucleic Acids Research 21 4272-4280.

Butler LM, Zhou X, Xu WS, Scher HI, Rifkind RA, Marks PA \& Richon VM 2002 The histone deacetylase inhibitor SAHA arrests cancer cell growth, up-regulates thioredoxin-binding protein-2, and down-regulates thioredoxin. PNAS 99 11700-11705.

Chen KS \& DeLuca HF 1994 Isolation and characterization of a novel cDNA from HL-60 cells treated with 1,25-dihydroxyvitamin D-3. Biochimica et Biophysica Acta 1219 26-32.

Chomczynski P \& Sacchi N 1987 Single-step method of RNA isolation by acid guanidinium thiocyanate-phenol-chloroform extraction. Analytical Biochemistry 162 156-159.

Church GM \& Gilbert W 1984 Genomic sequencing. PNAS 81 1991-1995.
De Feo VJ 1963 Determination of the sensitive period for the induction of the deciduomata in the rat by different inducing procedures. Endocrinology 73 488-497.

Fawcett DW 1950 The development of the mouse ova under the capsule of the kidney. Anatomical Record 108 71-91.

Finn CA \& Keen P 1963 The induction of deciduomata in the rat. Journal of Embryology and Experimental Morphology 11 673-682.

Goldberg SF, Miele ME, Hatta N, Takata M, Paquette-Straub C, Freedman LP \& Welch DR 2003 Melanoma metastasis suppression by chromosome 6: evidence for a pathway regulated by CRSP3 and TXNIP. Cancer Research 63 432-440.

Han SH, Jeon JH, Ju HR, Jung U, Kim KY, Yoo HS, Lee YH, Song KS, Hwang HM, Na YS, Yang Y, Lee KN \& Choi I 2003 VDUP1 upregulated by TGF- $\beta 1$ and 1,25-dihydroxyvitamin $D_{3}$ inhibits tumor cell growth by blocking cell-cycle progression. Oncogene 22 4035-4046.

Harvey MB, Leco KJ, Arcellana-Panlilio MY, Zhang X, Edwards DR \& Schultz GA 1995 Proteinase expression in early mouse embryos is regulated by leukaemia inhibitory factor and epidermal growth factor. Development 121 1005-1014.

Holmgren A \& Bjornstedt M 1995 Thioredoxin and thioredoxin reductase. Methods in Enzymology 252 199-208.

Ikarashi M, Takahashi Y, Ishii Y, Nagata T, Asai S \& Ishikawa K 2002 Vitamin $\mathrm{D}_{3}$ up-regulated protein 1 (VDUP1) expression in gastrointestinal cancer and its relation to stage of disease. Anticancer Research 22 4045-4048.

Junn E, Han SH, Im JY, Yang Y, Cho EW, Um HD, Kim DK, Lee KW, Han PL, Rhee SG \& Choi I 2000 Vitamin $D_{3}$ up-regulated protein 1 mediates oxidative stress via suppressing the thioredoxin function. Journal of Immunology 164 6287-6295.

Kennedy TG \& Ross HE 1997 Temporal- and hormone-dependent changes in uterine sensitization for the decidual cell reaction and decidualization in vitro of rat endometrial stromal cells. Journal of Reproduction and Fertility 109 129-136.

Kirby DR 1963 The development of mouse blastocysts transplanted to the scrotal and cryptorchid testis. Journal of Anatomy $\mathbf{9 7}$ 119-130.

Kirby DR 1965 The 'invasiveness' of the trophoblast. In The Early Conceptus, Normal and Abnormal, pp 68-74. Ed. WW Park. Edinburgh: University of St Andrews Press.

Liang P \& Pardee AB 1992 Differential display of eukaryotic messenger RNA by means of the polymerase chain reaction. Science $\mathbf{2 5 7}$ 967-971.

Martel D \& Psychoyos A 1978 Progesterone-induced oestrogen receptors in the rat uterus. Journal of Endocrinology 76 145-154.

Nishiyama A, Matsui M, Iwata S, Hirota K, Masutani H, Nakamura H, Takagi Y, Sono H, Gon Y \& Yodoi J 1999 Identification of thioredoxin-binding protein-2/vitamin $\mathrm{D}_{3}$ up-regulated protein 1 as a negative regulator of thioredoxin function and expression. Journal of Biological Chemistry 274 21645-21650.

Nishiyama A, Masutani H, Nakamura H, Nishinaka Y \& Yodoi J 2001 Redox regulation by thioredoxin and thioredoxin-binding proteins. IUBMB Life 52 29-33.

Osborne LJ, Tonissen KF, Tang VH \& Clarke FM 2001 Expression and localisation of thioredoxin in mouse reproductive tissues during the oestrous cycle. Molecular Reproduction and Development $\mathbf{5 8}$ $359-367$.

Perkins AV, Di Trapani G, McKay MS \& Clarke FM 1995 Immunocytochemical localization of thioredoxin in human trophoblast and decidua. Placenta 16 635-642.

Psychoyos A 1973 Endocrine control of egg implantation. In Handbook of Physiology, pp 187-215. Eds RO Greep, EB Astwood \& SR Geiger. Washington, DC: American Physiological Society.

Sahlin L, Holmgren A \& Eriksson H 1997 Thioredoxin messenger ribonucleic acid is regulated by estradiol in the rat uterus. Biology of Reproduction 57 1056-1059. 
Sambrook K, Fritsch E \& Maniatis T 1989 Molecular Cloning: A Laboratory Manual. Cold Spring Harbor, NY: Cold Spring Harbor Press.

Schulze PC, De Keulenaer GW, Yoshioka J, Kassik KA \& Lee RT 2002 Vitamin $\mathrm{D}_{3}$-upregulated protein-1 (VDUP-1) regulates redox-dependent vascular smooth muscle cell proliferation through interaction with thioredoxin. Circulation Research 91 689-695.

Simmons DG \& Kennedy TG 2000 Induction of glucose-regulated protein 78 in rat uterine glandular epithelium during uterine sensitization for the decidual cell reaction. Biology of Reproduction 62 $1168-1176$.

Smith CL \& Hammond GL 1991 Ontogeny of corticosteroid-binding globulin biosynthesis in the rat. Endocrinology 128 983-988.

de Vos S, Hofmann WK, Grogan TM, Krug U, Schrage $M$, Miller TP, Braun JG, Wachsman W, Koeffler HP \& Said JW 2003 Gene expression profile of serial samples of transformed B-cell lymphomas. Laboratory Investigation 83 271-285.
Yamanaka H, Maehira F, Oshiro M, Asato T, Yanagawa Y, Takei H \& Nakashima Y 2000 A possible interaction of thioredoxin with VDUP1 in HeLa cells detected in a yeast two-hybrid system. Biochemical and Biophysical Research Communications 271 796-800.

Yochim JM \& De Feo VJ 1963 Hormonal control of the onset, magnitude and duration of uterine sensitivity in the rat by steroid hormones of the ovary. Endocrinology 72 317-326.

Young LH, Yang X \& Voigt JM 1996 Alteration of gene expression in rat mammary tumors induced by $\mathrm{N}$-methyl- $\mathrm{N}$-nitrosourea. Molecular Carcinogenesis 15 251-260.

Received 1 October 2003

First decision 24 November 2003

Accepted 11 December 2003 